\title{
Mammalian small intestinal phytase (EC 3.1.3.8)
}

\author{
BY JOHN R. COOPER AND HELEN S. GOWING \\ National Radiological Protection Board, Chilton, Didcot, Oxon OXI1 ORQ
}

(Received 28 February 1983 - Accepted 10 June 1983)

1. Phytase (EC 3.1.3.8) concentration has been measured in the small intestine of rat, rabbit, guinea-pig and hamster. Levels varied from 0.12 units ( $\mu$ g phosphorus released $/ \mathrm{min}$ ) $/ \mathrm{mg}$ protein in the rat to $0.03 \mathrm{units} / \mathrm{mg}$ protein in the rabbit.

2. The enzyme is localized in the brush border of the small intestine of the rat.

3. It is suggested that the levels and location of phytase are an important factor in the uptake of metals from metal-phytate complexes. Metal ions released in the immediate vicinity of the absorptive surface of the intestine could be absorbed before being rendered insoluble by competing reactions such as hydrolysis.

Phytate (myo-inositol hexakisphosphate) is a common constituent of many foodstuffs including peas (Pisum sativum), bread and potatoes (Maga, 1982). It complexes a variety of essential minerals such as calcium, zinc, manganese and iron (Vohra et al. 1965). However, there is controversy over the absorption characteristics of metals ingested as their phytate complexes (Cheryan, 1980). For example, species-specific differences in the gastrointestinal uptake of plutonium phytate have been demonstrated (Cooper \& Harrison, 1982).

It is possible that variations in the levels of small intestinal phytase $(E C 3.1 .3 .8)$ could influence the uptake of metals. It has been suggested that phytase facilitates the gastrointestinal absorption of metals by breaking down the metal-phytate complex (Rackis \& Anderson, 1977). However, the opposite view that phytase has no effect has also been advanced (Morris \& Ellis, 1976). In an attempt to resolve this question the present work studies the levels of phytase and its subcellular distribution in the small intestinal mucosa of rat, rabbit, guinea-pig and hamster.

\section{MATERIALS AND METHODS}

Preparation of brush borders

The rats used were 3 to 4-month-old females (HMT strain; MRC Radiobiology Unit, Harwell), the rabbits were 1-year-old females (New Zealand Whites; Hop Rabbits, Canterbury, Kent), the guinea-pigs were 1-year-old males (MRC Radiobiology Unit, Harwell) and the hamsters were 15-month-old males (DSN strain; Intersimian Ltd, Abingdon).

After killing with diethyl ether, the small intestine was removed, washed with ice-cold saline $(9 \mathrm{~g}$ sodium chloride $/ \mathrm{l})$ and the mucosa expressed with a glass slide. The mucosa was suspended in $100 \mathrm{vol}$. of a medium containing $50 \mathrm{~mm}$-sucrose and $2 \mathrm{~mm}$-2-amino-2(hydroxymethyl)-propane-1,3-diol (Tris)-hydrochloric acid ( $\mathrm{pH} 7 \cdot 1$ ) and the brush borders isolated by the method of Schmitz \& Preiser (1973) but with magnesium chloride substituted for calcium chloride. For determination of phytase, the mucosa was homogenized in $30 \mathrm{vol}$. $50 \mathrm{~mm}$-sucrose plus $2 \mathrm{~mm}$-Tris- $\mathrm{HCl}(\mathrm{pH} 7 \cdot 1)$ using a Waring blender at full speed for $2 \mathrm{~min}$.

\section{Enzyme and chemical assays}

Phytase was estimated by the method of Cooper \& Gowing (1983). Briefly, enzyme, zinc chloride $(0.4 \mu \mathrm{mol}), \mathrm{MgCl}_{2}(4 \mu \mathrm{mol})$, sodium phytate $(3 \mu \mathrm{mol})$ and Tris- $\mathrm{HCl}$ buffer 
Table 1. Phytase levels (units ( $\mu \mathrm{g}$ phosphorus released/min)/mg protein) in the small intestinal mucosa

(Phytase levels in small intestinal mucosal homogenates were determined as described on p. 673. The results are expressed as mean values and standard deviations; no. of determinations given in parentheses)

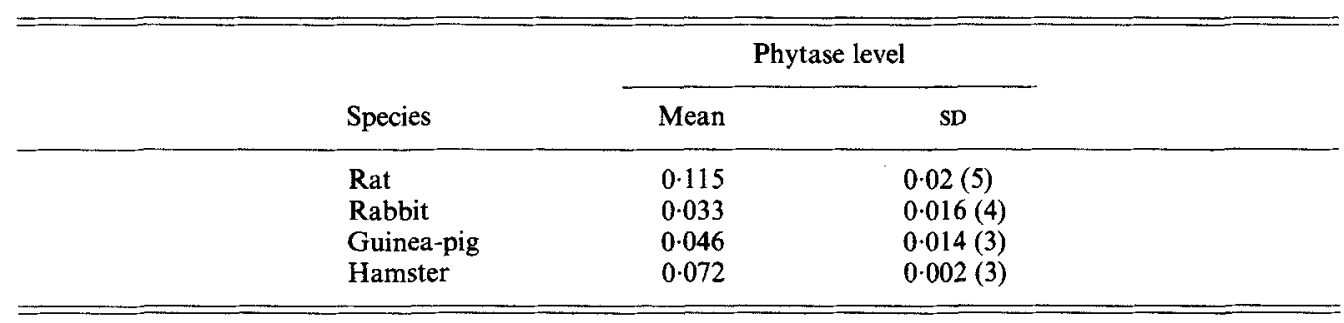

Table 2. Phytate hydrolysis by isolated intestinal segments

(The results are expressed as mean values and standard deviations with the no. of determinations on different animals given in parentheses. Sections $(350 \mathrm{~mm})$ of isolated proximal small intestine were filled

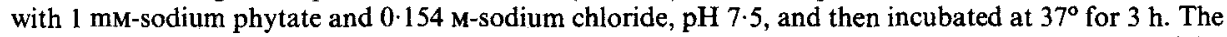
phytate remaining in the intestine was estimated by ion-exchange chromatography as described by Cosgrove (1980))

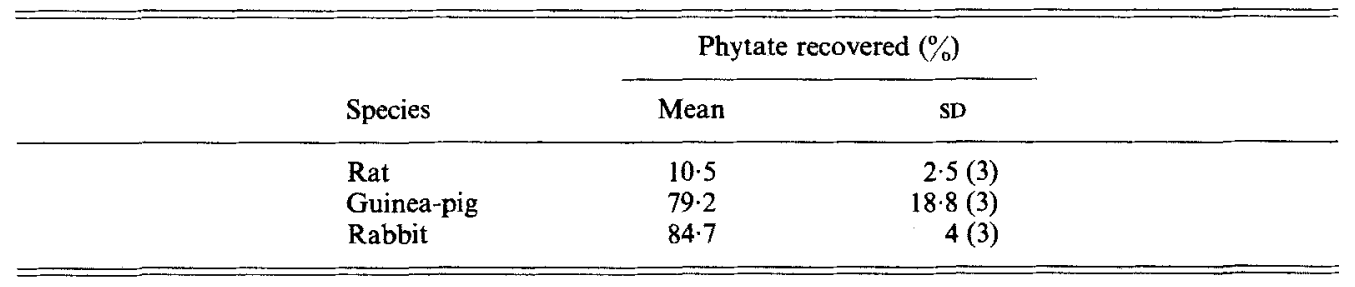

(40 $\mu \mathrm{mol}$ ) in a final volume of $2 \cdot 0 \mathrm{ml}$ were incubated at $37^{\circ}$ for $1 \mathrm{~h}$. The reaction was stopped

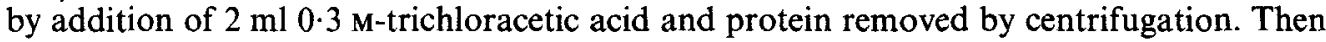
$0.5 \mathrm{ml}$ ammonium molybdate $(50 \mathrm{~g} / \mathrm{l})$ and $0.5 \mathrm{ml} 3 \mathrm{M}$-sulphuric acid were added while mixing. To prevent interference from phytate the phospho-molybdate complex was extracted into $2.5 \mathrm{ml} n$-butanol-heptane $(3: 2, \mathrm{v} / \mathrm{v})$. The organic layer was then added to $4 \mathrm{ml}$ aqueous ascorbic acid $(10 \mathrm{~g} / \mathrm{l})$ and the colour allowed to develop at $37^{\circ}$ for $2 \mathrm{~h}$. The optical density of the lower aqueous layer was measured in a Beckman Model 25 spectrophotometer (Beckman Instruments Inc., Irvine, USA) at $820 \mathrm{~nm}$.

Alkaline phosphatase (EC 3 1.3.1) was estimated by the method of Forstner et al. (1968), arylsulphatase (EC 3.1.6.1) by the method of Dodgson \& Spencer (1957) and succinic dehydrogenase $(E C 1.3 .99 .1)$ as described by Chambers \& Rickwood (1978).

Protein was determined by the Biuret method (Layne, 1957) and DNA by the method of Burton (1956). Phytic acid was estimated as inorganic phosphorus following purification by ion-exchange chromatography, according to the method of Cosgrove (1980).

\section{RESULTS}

Table 1 shows that the small intestinal mucosa of each of the four species studied contained measurable amounts of phytase. The levels ranged from 0.03 to 0.12 units $(\mu \mathrm{g} P$ released $/ \mathrm{min}) / \mathrm{mg}$ protein in the rabbit and rat respectively. The loss of phytate from isolated intestinal segments is shown in Table 2. The greatest loss was from the rat and the lowest from the rabbit. 
Table 3. The composition of isolated rat small intestinal brush borders

(The results are expressed as mean values and standard deviations for three separate brush-border preparations)

\begin{tabular}{|c|c|c|c|}
\hline \multirow[b]{2}{*}{ Component } & \multirow{2}{*}{$\begin{array}{c}\text { Organelle in } \\
\text { which localized }\end{array}$} & \multicolumn{2}{|c|}{ Amount present $(\%)^{*}$} \\
\hline & & Mean & SD \\
\hline Alkaline phosphatase $(E C 3.1 .3 .1)$ & Brush border & $36 \cdot 3$ & 5 \\
\hline Phytase $(E C 3.1 .3 .8)$ & - & $35 \cdot 0$ & 8 \\
\hline Arylsulphatase $(E C 3,1.6 .1)$ & Lysosomes & $1 \cdot 3$ & 0.5 \\
\hline Succinic dehydrogenase $(E C \quad 1.3 .99 .1)$ & Mitochondria & $4 \cdot 0$ & 1 \\
\hline Protein & - $\quad$. & $3 \cdot 0$ & 1.4 \\
\hline DNA & Nuclei & $9 \cdot 6$ & $1 \cdot 1$ \\
\hline
\end{tabular}

* The percentage recovery in the isolated brush-border preparation when compared with the initial mucosal homogenate.

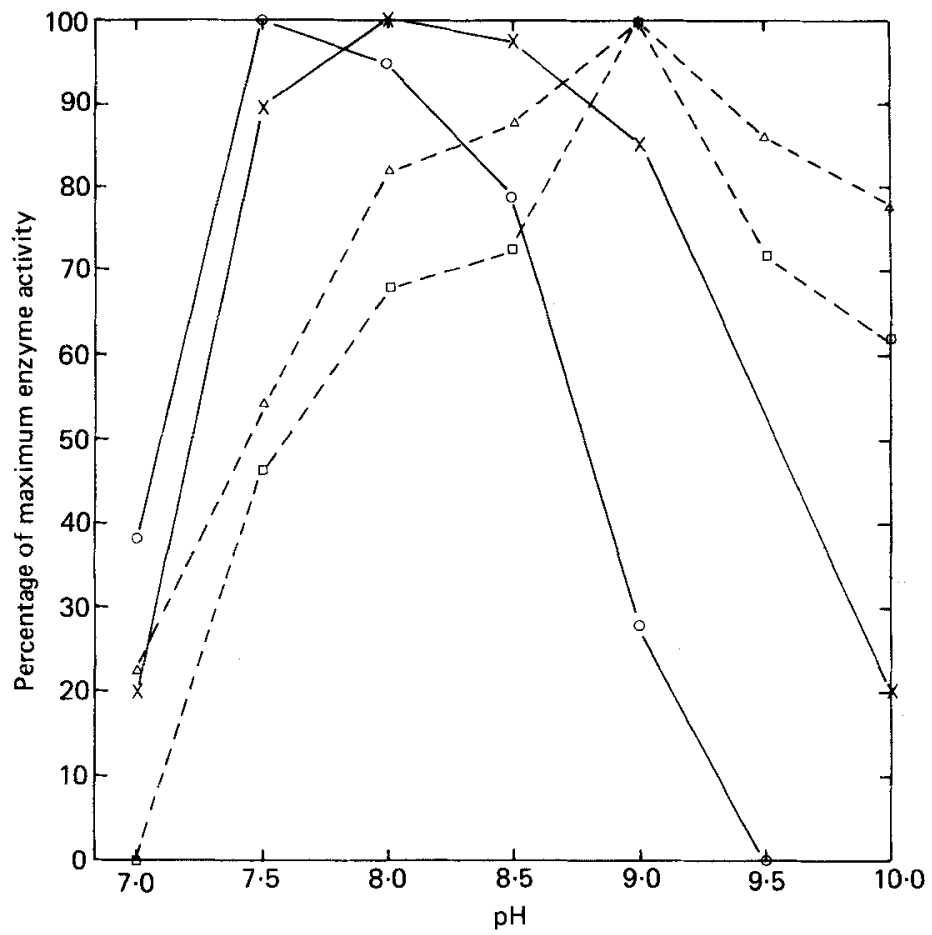

Fig. 1. pH dependence of phytase (EC 3 1.3.8) activity in intestinal homogenates. Portions of mucosal homogenate were assayed as described on p. 673. Tris-hydrochloric acid buffer was used in the $\mathrm{pH}$ range 7.0-9.0 and glycine-sodium hydroxide for $\mathrm{pH}$ values of 9.5 and $10.0 .(\times)$, Rat; $(O)$, tabbit; $(\triangle)$, hamster; $(\square)$, guinea-pig.

The subcellular distribution of the enzyme was studied in the rat. Brush-border vesicles were prepared and their purity determined by the use of the following marker enzymes: alkaline phosphatase (brush border), succinate dehydrogenase (mitochondria) and arylsulphatase (lysosomes). DNA was also measured as an index of contamination by nuclei. The results (Table 3 ) show that brush borders were prepared in $36 \%$ yield, in a relatively high state of purity and that phytase was localized in this membrane. 
Table 4. Effect of metal ions on rat small intestinal phytase (EC 3.1.3.8)

\begin{tabular}{ccccc}
\hline \hline \multicolumn{2}{c}{ Effect of $\mathrm{Zn}^{2+}$} & & \multicolumn{2}{c}{ Effect of $\mathrm{Mg}^{2+}$} \\
\cline { 1 - 1 } $\begin{array}{c}\text { Added } \mathrm{Zn}^{2+} \\
\text { concentration (mM) } \\
\left(2 \mathrm{mM}-\mathrm{Mg}^{2+} \text { added) }\right.\end{array}$ & Enzyme activity* & & $\begin{array}{c}\text { Added } \mathrm{Mg}^{2+} \\
\text { concentration (mM) } \\
\left(0 \cdot 2 \mathrm{mM}-\mathrm{Zn}^{2+} \text { added) }\right.\end{array}$ & Enzyme activity* \\
\hline 0 & 146 & 0 & 106 \\
$0 \cdot 1$ & 261 & 1 & 269 \\
$0 \cdot 2$ & 291 & 2 & 115 \\
0.4 & 183 & 8 & 291 \\
\hline
\end{tabular}

* Expressed as a percentage of the activity when no ions were added. Portions of rat intestinal homogenate were assayed as described on $\mathbf{p}$. 673 but with metal ions added as shown in the table.

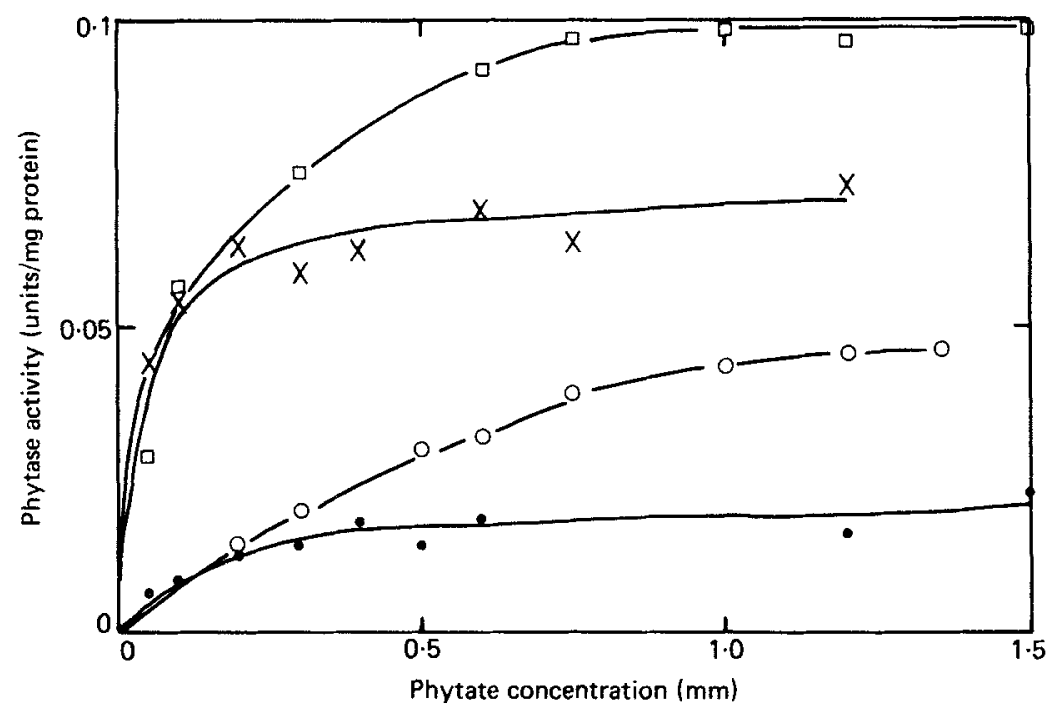

Fig. 2. The variation of phytase (EC 3.1.3.8) activity (units ( $\mu \mathrm{g}$ phosphorus released/min)/mg protein) with substrate concentration in intestinal homogenates. Portions of mucosal homogenate were assayed using increasing concentrations of sodium phytate. The assays were performed at the $\mathrm{pH}$ optima for each species (for details, see p. 673). ( $\square$ ), Rat; (O), rabbit; (O), guinea-pig; ( $\times$ ), hamster.

Some of the properties of phytase were investigated using intestinal homogenates. Enzyme activity was pH dependent (Fig. 1). The maximum activities with rabbit and rat enzymes were at $\mathrm{pH} 7.5$ and 8.0 respectively. Both hamster and guinea-pig enzymes had their optima at $\mathrm{pH} 9.0$ but the latter two species exhibited broader $\mathrm{pH}$-activity curves than the rabbit or rat. The effect of metal ions on enzyme activity is shown in Table 4 . The results are given for the rat but the same dependence was exhibited in the other three species.

The enzyme activity $v$. substrate concentration curves are shown in Fig. 2. To calculate kinetic factors, values for the velocity of the enzyme reaction at zero time are required. In the present experiments the velocity of the enzyme reaction was measured by stopping it at various times $(15,30$ or $60 \mathrm{~min})$ which were determined by the sensitivity of the method for estimating released phosphate. Therefore, in Fig. 2 the values for units/mg protein only approximate to the initial enzyme velocity. Nevertheless, for each species the enzyme activity appears to follow Michaelis-Menten kinetics. The values for the Michaelis constant $\left(K_{m}\right)$ 
determined using double-reciprocal plots were $0 \cdot 12,0 \cdot 11,0.82$ and $0.03 \mathrm{mM}$ for rat, rabbit, guinea-pig and hamster respectively. For the reasons outlined above these values must be considered approximate.

\section{DISCUSSION}

It is sometimes stated (Cheryan, 1980) that animals with one stomach do not possess an intestinal phytase. This is not so. The present results, together with those of Bitar \& Reinhold (1972), showed that phytase did occur in the small intestine although the concentrations varied between different species (Table 1). The rate of loss of phytate from isolated intestinal segments (Table 2) was directly related to phytase concentration and so phytate in the lumen of the intestine was accessible to the enzyme. When ${ }^{32} \mathrm{P}$-labelled phytate is fed to various mammals (Canals et al. 1954), the greatest uptake of ${ }^{32} \mathrm{P}$ and hence digestion of phytate is seen in the rat. A lower uptake occurred in the mouse and the rabbit, with the lowest being in the cat. The work by Canals et al. (1954) has been criticized because release of ${ }^{32} \mathrm{P}$ may have occurred by an exchange reaction rather than by digestion (Gillis et al. 1957). However, the conclusion that more digestion of phytate occurred in the rat than in the rabbit is confirmed by the present study.

Of the four species examined, phytase concentration has been measured previously only in the rat (Davies \& Flett, 1978). The latter workers found 0.274 units $/ \mathrm{mg}$ protein in the duodenal mucosa. This value compares with the present value of 0.115 units $/ \mathrm{mg}$ protein for entire small intestinal homogenate (Table 1). However, the levels of the enzyme are higher in the duodenum than in other regions of the intestine (Davies \& Flett, 1978) and this may account for the difference. The $\mathrm{pH}$ optimum for the rat enzyme (pH 8; Fig. 1) reported here is also similar to the values reported previously (Roberts \& Yudkin, 1961; Bitar \& Reinhold, 1972).

The dependence of enzyme activity on the presence of $\mathrm{Zn}^{2+}$ (Table 4) is similar to that reported by Davies \& Flett (1978). The effect of $\mathrm{Mg}^{2+}$ has not been previously studied extensively; however, Roberts \& Yudkin (1961) report that the enzyme activity is maximum at about $1 \mathrm{mM}-\mathrm{Mg}^{2+}$ in the rat. This compares with the present maximum at $2 \mathrm{~mm}$ (Table 4).

The phytase of all four species apparently obeys Michaelis-Menten kinetics (Fig. 2). Bitar \& Reinhold (1972) obtained similar results for the rat but reported that the phytase of chicken and calf was inhibited by substrate. However, it is important to note that the methods they used for estimating phytase may have influenced the results. Phytase was determined by measuring the phosphate released from the substrate. Any remaining phytate could interfere in the determination of phosphate by methods using the reduction of a phospho-molybdate complex (Irving \& Cosgrove, 1970; Cooper \& Gowing, 1983). The methodology used in the present study overcomes this problem by using a solvent-extraction step to separate the phosphate from the phytate.

The $K_{m}$ values of $0.03-0.8 \mathrm{~mm}$ obtained are similar to those reported for a variety of plant and microbial phytases (0.013-0.65 mM; Irving, 1980).

The subcellular localization of phytase is an important factor when its role in the uptake of metals bound to phytate is considered. Morris \& Ellis (1976) have argued that phytase is of little significance in aiding $\mathrm{Fe}$ absorption from soluble monoferric phytate because the metal ions released by the action of the enzyme would be rapidly hydrolysed at the $\mathrm{pH}$ of fluids in the small intestine to insoluble ferric hydroxide. This may be so if phytase is only present in the lumen of the small intestine. But in fact it is present at the surface of the mucosa (Table 3). Here it is proposed that it releases Fe from Fe-phytate in the immediate proximity of the absorptive surface. Thus absorption could occur before the competing reaction to form insoluble ferric hydroxide. Such a mechanism may explain the absorption pattern of plutonium when ingested as the plutonium(IV)-phytate complex. This metal 
resembles $\mathrm{Fe}(\mathrm{III})$ in some of its properties; for example, in its common tetravalent form it is readily hydrolysed at the small-intestinal $\mathrm{pH}$. When plutonium(IV)-phytate was fed to rats and rabbits of the same age and sex as used in the present study, the uptake of plutonium was higher $(0.13 \%)$ in the former than in the latter $(0.01 \%)$ species (Cooper \& Harrison, 1982). The result is consistent with the levels of phytase (Table 1) and digestion of phytate (Table 2) in the two species.

It is concluded that phytase is present in a variety of mammalian species and that the enzyme may have an important role in the availability of metals from soluble metal-phytate complexes.

\section{REFERENCES}

Bitar, K. \& Reinhold, J. G. (1972). Biochimica et Biophysica Acta 268, 442-452.

Burton, K. (1956). Biochemical Journal 62, 315-323.

Canals, E., Mariynan, R. \& Cordier, S. (1954). Bulletin de la Société de Chimie Biologique 36, 1015-1020.

Chambers, J. A. A. \& Rickwood, D. (1978). In Centrifugation: a Practical Approach, pp. 33-46 [D. Rickwood, editor]. London: Information Retrieval Ltd.

Cheryan, M. (1980). CRC Critical Reviews in Food Science and Nutrition 13, 297-335.

Cooper, J. R. \& Gowing, H. S. (1983). Analytical Biochemistry (In the Press.)

Cooper, J. R. \& Harrison, J. D. (1982). Health Physics, 43, 913-918.

Cosgrove, D. J. (1980). Journal of the Science of Food and Agriculture 31, 1253-1256.

Davies, N. T. \& Flett, A. A. (1978). British Journal of Nutrition 39, 307-316.

Dodgson, K. S. \& Spencer, B. (1957). Methods of Biochemical Analysis 4, 211-255.

Forstner, G. G., Sabesin, S. M. \& Isselbacher, K. J. (1968). Biochemical Journal 106, 381-390.

Gillis, M. B., Keane, K. W. \& Collins, R. A. (1957). Journal of Nutrition 62, 13-26.

Irving, G. C. J. (1980). In Inositol Phosphates, pp. 85-96, [D. J. Cosgrove, editor]. Oxford: Elsevier.

Irving, G. C. J. \& Cosgrove, D. J. (1970). Analytical Biochemistry 36, 381-388.

Layne, E. (1957). Methods in Enzymology 3, 447-451.

Maga, J. A. (1982). Journal of Agricultural and Food Chemistry 30, 1-9.

Morris, E. R. \& Ellis, R. (1976). Journal of Nutrition 106, 753-760.

Rackis, J. J. \& Anderson, R. L. (1977). Food Product Development 11, 38-44.

Roberts, A. H. \& Yudkin, J. (1961). British Journal of Nutrition 15, 457-47'

Schmitz, J. \& Preiser, H. (1973). Biochimica et Biophysica Acta 323, 98-112.

Vohra, P., Gray, G. A. \& Kratzer, F. H. (1965). Proceedings of the Society for Experimental Biology and Medicine 120, 447-449. 